\title{
ARTE NAIF
}

O segundo número do volume 13 do Anuário de Literatura põe na roda questões relacionadas à leitura, à literatura na infância e reflexões sobre as condições de possibilidade da Literatura.

São abordados, no primeiro caso, reflexões sobre livros destinados ao público infantil ou relacionados à infância. Os temas investigados giram em torno da tópica do medo como princípio organizador do relato e sobre a questão da diferença e do modo como se dá a representação dos grupos minoritários.

Também traz à baila artigos que giram em torno dos conceitos ou juízos de valor do que seja "literatura" e das diversas concepções da relação entre literatura e sociedade. Os textos discutem questões relativas à Literatura Comparada, passam pela investigação de escritos clássicos acerca do conceito de experiência, narração e memória e discorrem sobre o gênero epistolar, com especial relevo à interpenetração da prática das cartas-literatura e da literatura das cartas enquanto problematização das certezas biográficas. Finalmente, fechamos a presente edição com uma resenha sobre uma obra polêmica e original situada no âmbito dos estudos literários e culturais na contemporaneidade.

Não utilizamos as expressões "põe na roda" e "traz à baila" de ânimo leve. A arte naif, de Aracy, calha à perfeição como idéia norteadora deste número, pois evoca aquela noção barthesiana de que Literatura faz do saber uma festa.

Comissão Editorial 